\title{
書評を用いた図書に対する感性パラメータの自動設定 Automatic assignment of "Kansei" parameters to the books based on the words in online book reviews

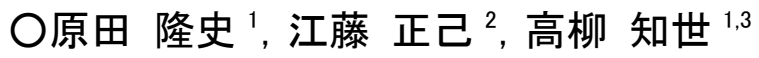 \\ Takashi HARADA, Masaki ETO, Tomoyo TAKAYANAGI
}

\author{
$1:$ :慶應義塾大学文学部図書館·情報学専攻 \\ School of Library and Information Science, Keio University \\ 于108-8345 東京都港区三田 2-15-45 \\ Email: ushi@slis.keio.ac.jp \\ 2 : 亜細亜大学非常勤講師 \\ Email: eto@slis.keio.ac.jp \\ 3 : 現在の所属は, 東京海上日動火災保険株式会社
}

近年, 感性に基づいて小説を検索できるシステムが開発され実用化されてきている。著者らも児童書を対象と してオンライン書評から感性を示すパラメータに值を設定し, 検索できるシステムを構築してきた。しかし, 人間 が付与するパラメータの值と書評中の語との関係の分析は十分に行われておらず, 書評中の語を元として感 性パラメータの值をどのように設定することが適切であるかは明らかとなっていない。本研究は, 書評中の「人 の感情や本の雰囲気を表す語」を元に機械学習の手法を用いて人間の判断と一致する感性パラメータの值を 付与する実験を行ったものである。図書 1605 冊分の書評を使って自動設定実験を行った結果, (1)自動設定 において書評中の語を使うことに有用性がある, (2)書評中のす心゙ての語を用いるよりも, 出現回数が多い 30 語程度を用いた方が効果的である, (3)書評中から抽出する語の品詞はほとんど再現率に影響しないことなど を明らかにすることができた。

In recent years Kansei retrieval systems have been developed to be practical use. We have developed the retrieval system using Kansei parameters based on online book reviews of children's books. The relation between parameters assigned manually and the words in online book-reviews has yet to be analyzed enough, however. Moreover, how to set appropriate value of Kansei parameters based on the words in online book reviews has not been theoretically proved. To resolve such problem, we have conducted an experiment. In this experiment, Kansei parameters which are consistent with the value gained manually were assigned based on "the words, which represent human feelings, impressions or atmosphere of books" using the machine learning approach. We have used 1605 book reviews to assign the parameters automatically. The result showed that : 1)using the words in book reviews is useful to assign parameters automatically, 2)using about 30 frequent words is more effective than using all the words in book reviews, and 3) the recall ratio is not influenced by the parts of speech of the words extracted from book reviews.

キーワード:オンライン書評, 感性検索, 感性パラメータ, 機械学習

Keyword: Online Book Review, Kansei Retrieval, Kansei Parameter, Machine Learning 


\section{1. ニーズに対応した読書指導の必要性}

子どもたちが図書館に行って本を選ぶ時, 多く の子どもは初めから目当ての本があって足を運 ぶわけではない。桑田の調査によると, 約 7 割の 生徒が, 借りたい本, あるいは読みたい本を決め る場合,「図書館に来てから決める」と回答して いる ${ }^{1)}$ 。図書を探す彼らに適切なアドバイスをす る存在が司書である。司書は, 子どもの年齢や興 味, 読解力に応じて, その子に適切であると思う 本を提供し, 子どもの知的成長を促すという大切 な役割を担う。しかし, 現在司書の不足が指摘さ れており,一人ひとりの子どもに最適な本を薦め ることができていないという現状にある。学校図 書館によっては, 常時勤務している司書がいない ところもあり，司書がいる学校といない学校で, 子どもの学習能力や情報収集能力, さらには生活 態度にも差がついていると報告されている ${ }^{2)}$

また, 一人の司書が把握できる本の数には限界 がある。適切な指導のために, 司書の間で本に対 する知識や情報に関するデータベースを共有し， 必要に応じて子どもたちの求める情報を適切に 提供できるシステムの必要も指摘される。

図書から感じる感情や雾囲気など幅広い図書 の評価から検索することができるシステムとし ては，英国の whichbook. net がある ${ }^{3)}$ 。しかし， whichbook. net は英語の図書を対象としており, 日本語の図書には対応していない。また, 文化の 違いなどから日本の図書を対象として whichbook. net をそのまま使用することはでき ない4)。

そこで著者らは, whichbook. net をモデルに， 図書の雰囲気・図書から受ける印象を表寸感性語 をもとにした図書検索が可能な日本独自のシス テムの試作を行った ${ }^{5)}$ ここのシステムは，人間の 感情に関して「楽しい-悲しい」のような 12 種類 の感性対を設定し（以下，「感性パラメータ」とす る)，これに 1 から 5 までの值を付与する方法を
用いている。感性パラメータに対する值の付与に 際しては，人手で行う機能を用意するとともに， オンライン書評中の形容詞および形容動詞 (以下, 「形容詞等」とする)を元に自動的に值を付与で きる仕組みもそなえている。試作したシステムを 用いた検索実験では, おおむね人間の判断と近い 図書が出力され，その有効性が確認された。なか でも, 専門家が人手によって感性パラメータに対 寸る值の付与を行った図書については適切に出 力されるという高い評価が得られた。ただし，才 ンライン書評中の語を元に感性パラメータの值 を付与した図書に関しては, 比較的評価が低かっ た ${ }^{5}$ 。

このような問題の原因としては, 以下の 2 点が 考えられる。

1）書評を元にした場合に值を付与できる感性 パラメータの数が比較的少なかったこと。実 際に, 入力用に設定した 12 個の感性語パラ メータのうち平均で 2.53 個のみにしか值が 付与されなかった。

2)形容詞等と感性パラメータとの関係に関す る分析が必ずしも十分ではなかったこと。

試作したシステムでは, オンライン書評中の語 を元にした感性パラメータに対する值の付与は, あくまで副次的なものであって, 専門家に後に修 正してもらうことを前提としていた。しかし, 日 本における専門家の数などを考えた場合, 専門家 の修正を前提とするシステムは現実的ではない。

本研究では専門家が入力したデータを元に, オ ンライン書評を用いてより適切な感性パラメー タの值の付与を行うための仕組みを開発するこ とを目的とした。

具体的には，1)に関して, 形容詞等のみではな く, 副詞, 名詞や動詞などについても利用するこ とで付与可能な感性パラメータ数を増やすとと もに，2）に関して，使用する語を感性に関わるも ののみに限定することとした。 


\section{2. 感性語パラメータの值付与に用いる書評}

本研究は, 書評中の形容詞等, 副詞, 動詞, 名 詞のうち, 人間の感情を表して思われる語を抽出 し, 人手により付与された感性語パラメータの值 と組み合わせて機械学習の手法を用いることで 自動付与を行おうとするものである。

まず，実験対象となる書評を選択するために， アマゾンジャパンの「こども」の中の「絵本」「児 童図書」「ノンフィクション」「童話」と，「新書・ 文庫」の中の「ヤングアダルト」「こども」に含 まれる図書 23487 冊を対象に, それらの持つ書評 数を調査した。その結果を第 1 表に示す。

第 1 表 アマゾンジャパンにおける临童書・YA図書の書評数

\begin{tabular}{|c|c|}
\hline 書評数（個） & 本の冊数 (冊) \\
\hline 0 & 16000 \\
\hline $1 \sim 2$ & 5754 \\
\hline $3 \sim 9$ & 1432 \\
\hline 10 以上 & 301 \\
\hline 計 & 23487 \\
\hline
\end{tabular}

第 1 表に示すように, 23487 冊中で少なくとも 1 つの書評がある図書は 7487 冊で, 10 個以上の 書評が存在する図書は 301 冊，3 個以上存在する 図書は 1,733 冊 (7.38\%)であった。なお，書評数 が最も多かった図書では 469 個の書評が作成さ れていた。

このうち, 本研究で用いるのに不適切あるいは 好ましくないものとして, 以下の条件にあてはま る書評があげられる。

1）書評の長さが 3 行以下のもの。

2）映画やドラマなどメディアミックス化され た困書に関する書評

3）ゲームソフトが本になったもの

4）ベストセラーや賞を受賞した作品

5）英語学習が目的の本

6）上下巻や 1〜 5巻というように 1 冊で完結し ていないものの 2 冊目以降
これらの書評は, 図書に関する感想ではなく, 別の観点からの書評がされていることが多く, 書 評が本の内容を表わさないことが多いと考えら れるためである。そこで，これらを除いても 3 個 以上の書評が存在する 1605 冊を実験対象とした。

\section{3. 書評中の語を基にした感性パラメータの付与}

形容詞等は感性を示すと言われるが，これらの 中にも感情を示すものではない語が多数含まれ る。たとえば,「白い」や「高い」などの語は, 人の感情や本の雰囲気を表す語とは言えない。名 詞・動詞などではさらに,この傾向は顕著である。

そこで，本の書評を「茶荃」6) を用いて形態素 解析し, 形容詞, 副詞, 動詞, 名詞を抽出し, 抽 出した語の中から人の感情や本の雰囲気を表す 語の選択を行った。語の選択に際して，形容詞， 副詞，動詞については，『感情表現辞典』7）を参 考に, 感情や本の雰囲気を示す語を抽出した。『感 情表現辞典』では, 感情を「喜・怒・哀・安・昂・ 好・驚・怖・恥・厭」という10 種類に分類して おり,それぞれに対応する語の例が 197 作家, 808 作品の中から抽出されて収録されている。本研究 では，この 10 種類に加えて，桑田らの研究の成 果も加味して「喜・怒・哀・安・昂・好・驚・怖・ 恥・厭, 軽, 遅, 気」という 13 種類を, 感情を 分類する際の基礎的な要素とした。

これら 13 の感情の種類と実際の語との関わり を見ると，「厭」と「好」の両方に該当するよう な, 複数の要素に関わる語が多数存在していた。 そこで本研究では，これらを別種の「複合した新 しい感情の種類」と考えて，13 種類の基本的な 要素に加えて，その組み合わせ 14 種類を含めた 27 種類の感情に関わる分類を設定した。27 種類 のうち, 実際に対応する語が存在していたものは, 形容詞等 17 種類, 副詞 19 種類, 動詞 20 種類で あった。

次に，書評中に出現した語を『感情表現辞典』 
に基づいて 27 種類の分類に分け, 分類ごとの出 現回数を数えた。『感情表現辞典』に掲載されて いない語については, 人手でどの分類に属するか を決定した。1 605 冊の書評中に出現した語のう ち, 感情を表す語の出現回数は, 形容詞等 18359 回, 副詞 3992 回, 動詞 14161 回であった。

名詞については, 他の品詞に見られるような感 情を示す分類との対応を行うことが困難であっ たため,「茶荃」によって抽出された名詞の頻出 数上位 100 位までの語の意味をもとに, 人手によ り 30 の分類を設定し，語との対応関係について も人手で判定を行った。

なお，人手による判定は 3 名が行い，そのうち 2 名が「人の感情や本の雰囲気を表現する」と判 定したものを採用するものとした。

\section{4. 機械学習による感性パラメータの值の付与}

4.1 機械学習による自動付与

感性各図書のパラメータごとの值の付与は, 上 記の分類ごとの出現語数と, 人手に基づく正解判
定結果の対を学習させ, 機械学習の手法により行 った。機械学習システムは, ワイカト大学で開発 された Weka を使用し ${ }^{8)}$, 判定器としては, 決定 木・ナイーブベイズ（以下，「ベイズ」とする）・ SVM の 3 種類を用いた。

対象図書 1605 冊を対象に，形容詞等をもとに して, 13 種の感性パラメータに対して, 決定木 とベイズ，SVM それぞれの判定器で判定を行った 際の正解数と再現率を第 2 表に示す。

第 2 表に示すように, いくつかの項目を除いて 35〜 55\%という再現率を得ることができた(第 2 表に網かけで示した)。本研究では 5 件法で付与 された值に対する再現率であり, 多くの項目で高 い再現率を出すことができたと考えられる。また， 5 件法で 1 段階ずれた值が付与されるところまで 「ほぼ正解」と見なした場合には, 全パラメータ の平均で $86.79 \%$ と高い再現率であった。このこ とは, 書評中の語を用いた機械学習によって図書 に対する感性パラメータの付与が効果的に行え ることを示していると言えよう。

第2表 決定木，ベイズ，SVMの比較（形容詞等をもとに值を付与した場合）

\begin{tabular}{|c|c|c|c|c|c|c|}
\hline & \multicolumn{2}{|c|}{ 決定木 } & \multicolumn{2}{|c|}{ ベイズ } & \multicolumn{2}{|c|}{ SVM } \\
\hline 感性パラメータ & 正解数 & 再現率 & 正解数 & 再現率 & 正解数 & 再現率 \\
\hline (1)ドキドキする - 冷めた & 687 & $42.80 \%$ & 648 & $40.37 \%$ & 693 & 43. $18 \%$ \\
\hline (2)びっくりする - 平凡な & 751 & $46.79 \%$ & 756 & $47.10 \%$ & 829 & $51.65 \%$ \\
\hline (3)心温まる-孤独な気持ち & 771 & $48.04 \%$ & 574 & $35.76 \%$ & 781 & $48.66 \%$ \\
\hline (4)夢の中の世界 - 現実的 & 490 & $30.53 \%$ & 553 & $34.45 \%$ & 609 & $37.94 \%$ \\
\hline (5)明るい - 恐い & 727 & $45.30 \%$ & 366 & $22.80 \%$ & 760 & $47.35 \%$ \\
\hline (6)和む - イライラする & 844 & $52.59 \%$ & 568 & $35.39 \%$ & 883 & $55.02 \%$ \\
\hline (7)爽やか - どんより & 638 & $39.75 \%$ & 672 & $41.87 \%$ & 707 & $44.05 \%$ \\
\hline (8)じーんとする-しらけた & 818 & $50.96 \%$ & 603 & $37.57 \%$ & 872 & $54.33 \%$ \\
\hline (9)元気が出る - がっかり & 766 & $47.73 \%$ & 774 & $48.22 \%$ & 840 & $52.34 \%$ \\
\hline 10楽しい - 悲しい & 577 & $35.95 \%$ & 539 & $33.58 \%$ & 581 & $36.20 \%$ \\
\hline 11)笑える - 深刻な & 711 & $44.30 \%$ & 640 & $39.88 \%$ & 758 & $47.23 \%$ \\
\hline 12あっさり - じっくり & 752 & $46.85 \%$ & 745 & $46.42 \%$ & 785 & $48.91 \%$ \\
\hline (13)展開の早い - もたもた & 1206 & $75.14 \%$ & 771 & $48.04 \%$ & 1217 & $75.83 \%$ \\
\hline 合計 & 9738 & $46.67 \%$ & 8209 & 39. 34\% & 10315 & 49. $44 \%$ \\
\hline
\end{tabular}


感性パラメータごとに詳細に見ていくと, 再現 率が比較的高いパラメータとしては,「展開のは やいーもたもたしている」および「和む一イライ ラ寸る」があげられる。特に前者はSVM 判定器の 場合で $75.83 \%$ と高い再現率を示した。これらの パラメータに共通の特徴としては, 書評中に各パ ラメータに関わる直接的な表現が多くみられた 項目ということである。また，同時に人手による 值の付与を行った場合に值のばらつきが少ない 傾向が見られたものでもあった。

逆に再現率が低いものとしては,「夢の中の世 界一現実的」および「楽しい一悲しい」があり， 決定木, SVM の両判定器を用いた場合, ともに再 現率 40\%以下であった。このうち，前者に関し ては,このような状況を表現するために使用され る語が非常に多岐にわたる内容であること，また， 後者については「基本的に楽しい本だけれども， 悲しい場面もある」などのように，局所的な感情 を表現する書評が多く見られるものであった。こ
のように, 書評中における図書の記述の精粗が大 きな原因と考えられる。

\section{2 判定器に関する分析}

決定木, ベイズ, SVM の 3 種の判定器を比較し た結果, 全感性パラメータに関する平均再現率は 決定木 $46.67 \%$ ，ベイズ $39.34 \%$, SVM $49.43 \%$ で あった。ベイズ判定器は特に大規模なデータを対 象とした場合に適切な手法とされ，本研究で用い た 1605 件のデータでは充分な効果が上がらなか ったことが理由として考えられる。

決定木および SVM 判定器の比較では, ほとんど 全ての感性パラメータの平均再現率で SVM 判定 器の方が決定木判定器を使用する場合よりも約 3\%高いという結果となった。しかし，SVM 判定 器を用いて感性パラメータに值を付与する時間 は決定木判定器を用いる場合に比較して長く, 計 算コストは大きい。実際のシステムへの応用を考 えると，時間のコストは低いことが望ましい。そ

第3表 品詞による再現率の比較 (決定木判定器を用いた場合)

\begin{tabular}{|c|c|c|c|c|}
\hline 感性パラメータ & 形容詞等 & 副詞 & 動詞 & 名詞 \\
\hline (1)ドキドキする-冷めた & $687(42.8 \%)$ & $736(45.86 \%)$ & $712(44.36 \%)$ & $694(43.24 \%)$ \\
\hline (2)びっくりする-平凡な & $751(46.79 \%)$ & $797(49.66 \%)$ & $794(49.47 \%)$ & $693(49.41 \%)$ \\
\hline (3)心温まる - 孤独な気持ちになる & $771(48.04 \%)$ & $730(45.48 \%)$ & $785(48.91 \%)$ & $777(48.41 \%)$ \\
\hline (4)夢の中の世界 - 現実的 & $490(30.53 \%)$ & $567(35.33 \%)$ & $555(34.58 \%)$ & $553(34.45 \%)$ \\
\hline (5)明るい - 恐い & $727(45.3 \%)$ & $757(47.17 \%)$ & $706(43.99 \%)$ & $702(43.74 \%)$ \\
\hline (6)和む - イライラ寸る & $844(52.59 \%)$ & $883(55.02 \%)$ & $858(53.46 \%)$ & $825(51.4 \%)$ \\
\hline (7)爽やか - どんより & $638(39.75 \%)$ & $691(43.05 \%)$ & $683(42.55 \%)$ & $674(41.99 \%)$ \\
\hline (8)心がじーんとする-しらけた & $818(50.97 \%)$ & $841(52.4 \%)$ & $838(52.21 \%)$ & $862(53.71 \%)$ \\
\hline (9)元気が出る - がっかりする & $766(47.73 \%)$ & $816(50.9 \%)$ & $793(49.41 \%)$ & $791(49.28 \%)$ \\
\hline (10)楽しい - 悲しい & $577(35.95 \%)$ & $592(36.88 \%)$ & $557(34.7 \%)$ & $536(33.4 \%)$ \\
\hline (11)笑える - 深刻な & $711(44.3 \%)$ & $739(46.04 \%)$ & $697(43.43 \%)$ & $674(41.99 \%)$ \\
\hline (12)あつさり読める - じっくり読める & $752(46.85 \%)$ & $784(48.85 \%)$ & $738(45.98 \%)$ & $744(46.36 \%)$ \\
\hline (13)展開のはやい - もたもた & $1206(75.14 \%)$ & $1213(75.58 \%)$ & $1208(75.26 \%)$ & $1190(74.14 \%)$ \\
\hline 合 & $9738(46.67 \%)$ & $10147(48.63 \%)$ & $9923(47.56 \%)$ & $9815(47.04 \%)$ \\
\hline
\end{tabular}


の点を加味して考えた場合, 分析結果が短時間で 出る決定木の方が適しているとも考えられる。

\section{3 品詞による比較}

形容詞等をもとにした場合と同様に，副詞，動 詞, 名詞についても感性パラメータに対する值の 付与を行い，その再現率を第 3 表に示した。

全ての感性パラメータを対象とした再現率は 形容詞 $46.67 \%$, 副詞 48.63\%, 動詞 $47.56 \%$, 名詞 $47.04 \%$ とほとんど差はなかった。

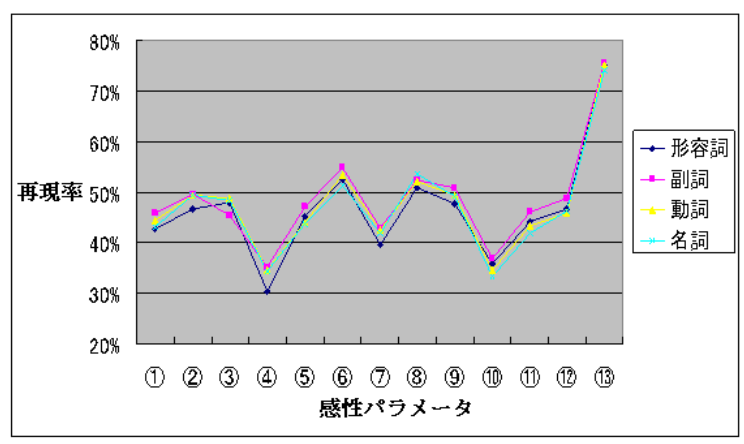

第1図 各品詞ごとの感性パラメータに対する再現率の違い
第 1 図は, 品詞によって, 感性パラメータごと に, その值を付与する時の再現率に差があるかど うかを示すために作成したグラフである。

第 1 図にみられるように, 全ての感性パラメー タに対する再現率だけではなく, 感性パラメータ ごとに比較した場合にも再現率に差がみられな かった。このように差がみられない結果は，3つ の判定器のいずれを用いた場合も同様の結果で あった。

4.4 実験に用いた分類の妥当性, 書評数の違い による相違の分析

どの判定器を用いた場合においても, 品詞によ る差が見られなかった原因として以下の 2 つが 考えられる。

1) 実際に出現する語を 27 種類の分類ごとにま とめたことが悪影響を及ぼしている可能性

2) 図書によって付与されている書評数が異な り出現する語数にも差があることが悪影響 を及ぼしている可能性

第 4 表 語をもとにした付与，および，正規化して付与した結果(形容詞等をもとに值を付与した場合)

\begin{tabular}{|c|c|c|c|c|c|c|}
\hline & \multicolumn{2}{|c|}{ もともとの手法 } & \multicolumn{2}{|c|}{ 語をもとにした付与 } & \multicolumn{2}{|c|}{ 正規化して付与 } \\
\hline 感性パラメータ & 正解数 & 再現率 & 正解数 & 再現率 & 正解数 & 再現率 \\
\hline (1)ドキドキする - 冷めた & 687 & $42.80 \%$ & 710 & $44.24 \%$ & 678 & $42.24 \%$ \\
\hline (2)びっくりする - 平凡な & 751 & $46.79 \%$ & 796 & $49.60 \%$ & 787 & 49. $03 \%$ \\
\hline (3)心温まる - 孤独な気持ち & 771 & $48.04 \%$ & 808 & $50.34 \%$ & 796 & $49.60 \%$ \\
\hline (4)夢の中の世界 - 現実的 & 490 & $30.53 \%$ & 490 & $30.53 \%$ & 483 & $30.09 \%$ \\
\hline (5)明るい - 恐い & 727 & $45.30 \%$ & 713 & $44.42 \%$ & 723 & $45.05 \%$ \\
\hline (6)和む - イライラする & 844 & $52.59 \%$ & 852 & $53.08 \%$ & 853 & $53.15 \%$ \\
\hline (7)㸚やか - どんより & 638 & $39.75 \%$ & 638 & $39.75 \%$ & 594 & $37.01 \%$ \\
\hline (8)しーんとする-しらけた & 818 & $50.96 \%$ & 845 & $52.65 \%$ & 818 & $50.97 \%$ \\
\hline (9)元気が出る - がっかり & 766 & $47.73 \%$ & 776 & $48.35 \%$ & 750 & $46.73 \%$ \\
\hline 10楽しい - 悲しい & 577 & $35.95 \%$ & 621 & $38.69 \%$ & 594 & $37.01 \%$ \\
\hline 111笑える - 深刻な & 711 & $44.30 \%$ & 689 & $42.93 \%$ & 678 & $42.24 \%$ \\
\hline 12)あっさり - じっくり & 752 & $46.85 \%$ & 750 & $46.73 \%$ & 700 & $43.61 \%$ \\
\hline (13)展開の早い-もたもた & 1206 & $75.14 \%$ & 1202 & $74.89 \%$ & 1215 & $75.70 \%$ \\
\hline 合計 & 9738 & $46.67 \%$ & 9890 & $47.40 \%$ & 9669 & $46.34 \%$ \\
\hline
\end{tabular}


そこで, 形容詞等を用いて感性パラメータに值 を付与する際に，1） 27 種類の分類に分けた上で 感性パラメータを付与した場合と出現した語を そのまま使用して感性パラメータを付与した場 合の比較，および，2）それぞれの語の出現回数 を書評数で除して正規化した上で值の付与する 実験を行った。その結果を第 4 表に示す。

第 4 表に見られるように, 形容詞等を感情表現 で分類したものを用いた場合の再現率は全体で $46.67 \%$, 形容詞そのものを用いた場合の再現率 は 47. 40\%と，ほとんど変わらない結果であった。

また, 語の出現回数を書評数で除して正規化し た場合についても, その再現率はほとんど変化が なかった。

\section{5 決定木判定器で用いられたルールの分析}

決定木判定器では, 機械が学習した結果を樹形 図の形として分析することが可能である。

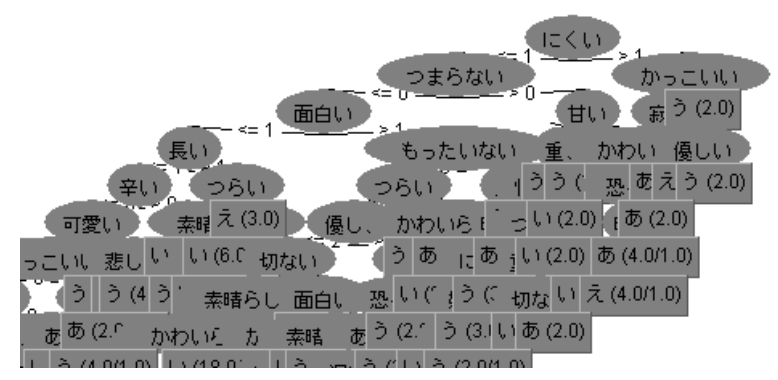

第 2 図 決定木判定器で作成されたルールの例

第 2 図は, 形容詞等を用いて決定木判定器を用 いた場合のルールを示したものである。樹形図で 示されるルールの上部 (根元)にあたる部分に表 示される語ほじ, 感性パラメータに值を付与する 際の影響力が強い語であると考えられる。

そこで, 形容詞等を用いて決定木判定器を用い た場合に, 感性パラメータに值を付与する際に作 成される樹形図の上位に示される語の分析を行 った。第 5 表に上部に出現した語の例を示す。

これらの語は, 書評中における出現回数の多い
第 5 表 決定木判定器の樹形図から読み取れる 感性語に影響を与えている語（形容詞等）

\begin{tabular}{|c|c|c|c|}
\hline $\begin{array}{c}\text { (1)ドキドキ- } \\
\text { 冷めたい }\end{array}$ & $\begin{array}{c}\text { (2)びっくり- } \\
\text { 平凡な }\end{array}$ & $\begin{array}{l}\text { (3)心温まる- } \\
\text { 孤独気持ち }\end{array}$ & $\begin{array}{l}\text { (4) 夢の中の } \\
\text { 世界-現実的 }\end{array}$ \\
\hline にくい & 恐ろしい & あたたかい & 面白い \\
\hline $\begin{array}{l}\text { かっこいい } \\
\text { つまらない }\end{array}$ & 怖い・可愛い & $\begin{array}{l}\text { 優しい・ } \\
\text { 切ない }\end{array}$ & つらい・重い \\
\hline $\begin{array}{l}\text { 寂しい・甘 } \\
\text { い・面白い }\end{array}$ & $\begin{array}{l}\text { 懐かしい・寂 } \\
\text { しい（怖い） }\end{array}$ & $\begin{array}{l}\text { かわいらし } \\
\text { い・かっこい } \\
\text { い.興味深い }\end{array}$ & $\begin{array}{l}\text { 深い・辛い. } \\
\text { かわいらし } \\
\text { い }\end{array}$ \\
\hline
\end{tabular}

\begin{tabular}{|c|c|c|c|}
\hline $\begin{array}{l}\text { (5)明るい- } \\
\text { 恐い }\end{array}$ & $\begin{array}{l}\text { (6)和む一 } \\
\text { イライラ }\end{array}$ & $\begin{array}{c}\text { (7)爽やか- } \\
\text { どんより }\end{array}$ & $\begin{array}{l}\text { (8) じーんす } \\
\text { るーしらける }\end{array}$ \\
\hline 怖い & 優しい & 怖い & あたたかい \\
\hline $\begin{array}{l}\text { 楽しい・嬉し } \\
い\end{array}$ & $\begin{array}{l}\text { かわいらし } \\
\text { い・懐かしい }\end{array}$ & $\begin{array}{l}\text { 懐かしい. } \\
\text { あたたかい }\end{array}$ & $\begin{array}{l}\text { 切ない・にく } \\
\text { い }\end{array}$ \\
\hline $\begin{array}{l}\text { 明るい・辛い } \\
\text { 可愛い・深い }\end{array}$ & $\begin{array}{l}\text { 暗い・面白 } \\
\text { い・素晴しい }\end{array}$ & $\begin{array}{l}\text { 暗い・痛い・ } \\
\text { 興味深い }\end{array}$ & $\begin{array}{l}\text { つらない・ } \\
\text { 面白い・興味 } \\
\text { 深い }\end{array}$ \\
\hline
\end{tabular}

\begin{tabular}{|c|c|c|c|}
\hline $\begin{array}{l}\text { (9)元気でる } \\
\text {-がっかり }\end{array}$ & $\begin{array}{c}\text { (10楽しい- } \\
\text { 悲しい }\end{array}$ & $\begin{array}{c}\text { (11)笑える- } \\
\text { 深刻な }\end{array}$ & $\begin{array}{c}\text { (12)あっさり- } \\
\text { じっくり }\end{array}$ \\
\hline 怖い & 悲しい & 楽しい & 楽しい \\
\hline $\begin{array}{l}\text { かわいらし } \\
\text { い・暖かい }\end{array}$ & $\begin{array}{l}\text { 楽しい。 } \\
\text { 物足りない }\end{array}$ & $\begin{array}{l}\text { 辛い・悲し } \\
\text { い }\end{array}$ & $\begin{array}{l}\text { 暖かい。 } \\
\text { 面白い }\end{array}$ \\
\hline $\begin{array}{l}\text { 優しい・ } \\
\text { 軽い・重い }\end{array}$ & $\begin{array}{l}\text { 切ない・かっこ } \\
\text { いい・優しい } \\
\text { 懷かしい }\end{array}$ & $\begin{array}{l}\text { 痛い・切な } \\
\text { い・物足り } \\
\text { ない }\end{array}$ & $\begin{array}{l}\text { かわいらし } \\
\text { い(楽しい) }\end{array}$ \\
\hline
\end{tabular}

\begin{tabular}{|l|}
\hline (13)展開が早い-もたもた \\
\hline 楽しい \\
\hline あたたかい・面白い \\
\hline かわいらしい・(楽しい) \\
\hline
\end{tabular}


語とも一致していた。特に「怖い」「楽しい」「面 白い」「あたたかい」「悲しい」などは出現回数が 多かった。書評中の出現頻度の上位 30 語のうち, 第 5 表にない語は「長い」と「もったいない」の 2 語のみであった。

\section{5. 感性語を元にした図書検索システムの将来}

本研究では現在増えている書評に着目し, 書評 中に含まれる語の中から「人の感情や本の雾囲気 を表す語」を抽出して, 機械学習を用いて図書評 価を自動付与することの有用性を明らかにした。

本研究で実現できた感性パラメータへの值付 与の再現率は，5件法で值が 1 段階ずれるところ まで許容した場合には 90\%近い再現率であり, 書 評を用いて感性パラメータを付与寸ることの妥 当性を示していると考えられる。

また, 書評中の形容詞等, 副詞, 動詞, 名詞の 4 つの品詞のいずれを用いた場合でも，ほとんど 同じ再現率であることは非常に興味深い結果と 考えられる。すなわち, この結果は機械学習法を 用いる場合には, 語の品詞による差を意識せずに, 感性を示すと考えられる語をまとめて取り扱う ことでできる可能性を示唆しているといえよう。

ただし，本研究で取り扱った図書の数は 1605 冊と，それほど多くはなく，このことが機械学習 法を用いる場合にはどの品詞を用いた場合でも 同じ傾向を示寸結果につながっている可能性も ある。大量のデータを対象とした場合にも, 品詞 による差を意識する必要がないのかどうかにつ いては，さらに検討する必要があろう。

書評数を増や寸という点については, 今後, ネ ットワークの発展にともなって, ネットワーク上 に存在する書評の数は増加すると考えられる。才 ンライン書店の書評だけでなく, ブログやソーシ ヤルネットワークの活用も検討していきたい。

さらに, 13 種の感性パラメータの中には再現 率が低い項目もあり, 決定木の樹形図をさらに検
討するなどを通じて, さらに書評中の語と感性語 との対応関係を分析していく必要があるだろう。

\section{6. 引用文献}

1）桑田てるみ. 生徒の読書材選択行動および選 択要因の特徵 - - 有効な読書案内に向けて の考察. 三田図書館・情報学会研究大会発表 論文集。三田図書館・情報学会.Vo1, 2006 年度, p. 73-76

2）山形県鶴岡市立朝陽第一小学校.「図書館活用 教育」を学校経営の中核に据え心豊かな生涯 学習者を育む。全国学校図書館協議会, 2004, 47p.

3) Whichbook. net. [2007-07-15] $\langle$ http://www. whichbook. net/〉

4) 桑田てるみ。英国の読書検索サイト “whichbook. net”のわが国における意義とそ の可能性 : 学校図書館員が読書案内に利用寸 る視点から. 三田図書館 - 情報学会研究大会 発表論文集. 三田図書館・情報学会. Vol. 2004 年度, $\mathrm{p} 5-8$

5）桑田てるみ, 原田隆史, 小林加奈. 感性語を 検索語とした読書資料検索システムの開発に 関寸る基礎研究 - 日本版 whichbook の作成. 学校図書館学研究. 日本学校図書館学会. Vol. 8, 2006, p. 3-20

6）原田隆史．書評中の感性語を用いた览童書・ ヤングアダルト図書の自動分類. 情報知識学 会. Vol. 15, No. 2, 2005, p. 57-62.

7) 形態素解析ソフトウェア「茶荃」. [2007-10-27] $\langle$ http://chasen-1egacy. sourceforge. jp/〉

7）中村明. 感情表現辞典. 東京, 大興出版, 1979, 456p.

8) Weka 3 - Data Mining with Open Source Machine Learning Software in Java. [2007-08-06] $\langle$ http://www. cs. waikato. ac. nz/ml/weka/〉 